\title{
Gramsci, os intelectuais e suas funções científico-filosófica, educativo-cultural e política
}

\author{
Marcos Francisco Martins ${ }^{*}$
}

Resumo: À luz da concepção gramsciana de intelectual, vista sob o prisma do engajamento político, o texto apresenta uma leitura de suas funçōes científico-filosófica, educativo-cultural e política, na disputa pela hegemonia que se trava entre as classes na realidade capitalista. Destaca-se a dificuldade de conceituar o termo "intelectual", pois ele suscita significados variados e é utilizado de diferentes formas para identificar indivíduos e/ou grupos sociais na ação sociopolítica e educativa; e apresenta-se a concepção gramsciana de intelectual, orientada pela marxiana categoria de classe.

Palavras-chave: Antônio Gramsci; educação; engajamento; hegemonia; intelectuais.

\section{Gramsci, the intellectuals and their scientific-philosophical, educational-cultural and political roles}

Abstract: Based on the Gramscian concept of intellectuals, seen through the political engagement perspective, the text presents a reflection on their scientific-philosophical, educational-cultural and political roles in the struggle for hegemony among the classes in a capitalist environment. It is here highlighted the difficulty in conceptualizing "intellectual", because the term generates various meanings and is used in different ways to identify individuals and/or social groups in social-political and educational actions, and we present the Gramscian conception of intellectual, driven by the Marxian class category.

Key words: Antonio Gramsci, education, engagement, hegemony, intellectuals.

\section{Introdução}

O objetivo deste texto é apresentar a concepção de Gramsci sobre os intelectuais e refletir sobre o papel que eles podem desempenhar na disputa pela hegemonia, quando engajados organicamente às classes sociais fundamentais: o científico-filosófico, o educativo-cultural e o político.

Em especial, é discutida a função educativo-cultural dos intelectuais na disputa entre as classes pela dominação e direção das relações sociais. Todavia, não é obje-

Professor adjunto da Universidade Federal de São Carlos (UFSCar) - campus Sorocaba, SP, Brasil. Bolsista de Produtividade em Pesquisa do Conselho Nacional de Desenvolvimento Científico e Tecnológico (CNPq).marcosfranciscomartins@gmail.com 
tivo do presente texto esmiuçar o conceito de educação formulado por Gramsci, mas identificá-lo ao ponto de ter clareza em relação ao papel educativo-cultural que este autor atribuiu aos intelectuais, o qual deve ser desenvolvido de forma articulada com as funçōes científico-filosófica e política.

Dada a amplitude das abordagens existentes sobre os intelectuais e seu papel, adota-se como fio condutor da exposição a relação entre intelectual e engajamento político, perspectiva consoante ao paradigma teórico-metodológico gramsciano, que a ela acrescenta a categoria marxiana de classe social.

\section{engajamento político dos intelectuais como fio condutor da exposição}

"Intelectual" é palavra amplamente utilizada no ambiente acadêmico-científico e na seara sociocultural das sociedades atuais. A amplitude de seu uso resulta em enorme dificuldade aos que pretendem investigá-lo e conceituá-lo, pois o termo "intelectual" pode ser abordado por diferentes enfoques, sustentados em variadas referências heurísticas.

Dentre as formas de tomar os intelectuais com vista à conceituação, destacam-se três: a) o enfoque da produção e da socialização do conhecimento por um grupo social especializado; b) o enfoque da produção cultural, que pode resultar na clássica distinção entre "cultura erudita" e "cultura popular"; c) e o enfoque da diferença entre "trabalho concreto" (produtor de valor-de-uso) e "trabalho abstrato" (produtor de valor-de-troca), como faz Marx (1999), por exemplo, a partir da referência à categoria de classe social.

Desses possíveis enfoques, resultam diferentes sentidos ao uso do termo "intelectual", mas principalmente dois:

Ao substantivo Intelectuais podem ser atribuídos dois sentidos principais, aparentemente semelhantes mas substancialmente diferentes. Em primeiro lugar, ele designa uma categoria ou classe social particular, que se distingue pela instrução e competência, científica, técnica ou administrativa, superior à média, e que compreende aqueles que exercem atividades ou profissōes especializadas [...] uma segunda acepção, mais vulgar na publicidade de atualidade literária e política, para a qual Intelectuais são os escritores "engajados". Por extensão, o termo se aplica também a artistas, estudiosos, cientistas e, em geral, a quem tem adquirido, com o exercício da cultura, uma autoridade e uma influência nos debates públicos. (Bobbio; Matteucci; Pasquino, 1992, p. 637)

Tais sentidos da palavra “intelectual”, por serem bastante próximos, não ajudam a conceituação, embora a segunda posição remeta a questão para um debate mais 
frutuoso aos marxistas em geral e, particularmente, a Gramsci — o da relação entre a atividade do intelectual e o envolvimento com a disputa pelo poder. Daí a opção de, neste texto, enfrentar o debate, tomando, em parte, como referência, o segundo enfoque, que é próximo ao do comunista da Sardenha. Próximo mas não idêntico, porque a posição gramsciana adota como referência a categoria marxiana de classe social.

Orientada a exposição a partir do engajamento político dos intelectuais, pode-se dizer que há os que vivenciaram a luta pela definição dos contornos da vida sociopolítica, como Gramsci, e há também alguns que apenas defenderam o engajamento político e, mesmo assim, mantiveram-se distantes dos embates dele decorrentes, em oposição a outros que rechaçaram completamente essa posição (Ortega y Gasset, 1971).

Gramsci contribuiu no processo de elaboração de um conceito intelectual e o fez por meio de uma perspectiva classista, o que lhe possibilitou identificar a seara do trabalho intelectual também como um espaço em que se desenvolve a disputa pela hegemonia. Na primeira metade do século XX, Gramsci tratou dessa questão de maneira original, legando ao presente a possibilidade de distinguir o engajamento político mediado pela visão classista de outros tipos de engajamento, que podem ser intercedidos, por exemplo, por valores morais, espírito religioso, concepção filosófica, identidade de grupo (étnica, de gênero, opção sexual, faixa etária, etc. $)^{1}$, etc. Assim, Gramsci se tornou uma referência nessa questão até os dias atuais, mormente àqueles que assumem o materialismo histórico e dialético como paradigma científico e filosófico de análise da realidade concreta e guia para a ação sociopolítica e educacional-cultural.

\section{Gramsci e o engajamento político do intelectual à luz da categoria de classe}

Gramsci não tem uma formulação a priori sobre os intelectuais. Ao contrário, consoante à sua matriz teórico-metodológica, o materialismo histórico e dialético (cf. Martins, 2008), ele analisou a função que os intelectuais desempenharam na dinâmica da vida para definir a totalidade social em uma determinada conjuntura,

I. Cf., por exemplo, o engajamento político atual de muitos intelectuais vinculados aos chamados Novos Movimentos Sociais (NMS), que se mobilizam contra aspectos específicos do processo de exploração, alienação e exclusão resultante da dinâmica do modo de vida capitalista, mas relegam ao segundo plano a determinação da base material na vida social e mesmo o peso da categoria de classe, que é central a marxistas como Gramsci (Cf. Gohn, 2009; Picolotto, 2007). Nesse sentido, tais intelectuais engajados aos NMS preocupam-se primordialmente com a equalização de alguns problemas inerentes à dinâmica do capitalista, mas não necessariamente com a superação desse tipo de vida que se assenta na contradição de classe.

Pro-Posições, Campinas, v. 22, n. 3 (66), p. 131-148, set./dez. 2011 
tendo como referência as disputas que as classes sociais travaram entre si, com vista a consolidar um "bloco histórico", um conjunto articulado e contraditório de forças estruturais e superestruturais que expressa o conjunto das relaçôes sociais de produção (Gramsci, 1999, p. 250) e estabelece, por meio de relações recíprocas, os princípios, as finalidades, a dinâmica, os limites e as possibilidades de funcionamento do modo de vida.

A partir do paradigma que o orientou, Gramsci produziu um conceito de intelectual que, muitas vezes, é equivocadamente interpretado e utilizado abstratamente ${ }^{2}$. Para evitar isso, é importante considerar que o fio condutor da análise gramsciana sobre os intelectuais reside no papel que desempenham na disputa pela hegemonia entre as classes de uma determinada formação econômica e social, que foi a da Itália, em particular, e a Europa, em geral, no período correspondente à primeira metade do século XX. Nesse sentido, "Na abordagem gramsciana, a questão dos intelectuais dizia respeito às formas de exercício das funções de direção e dominação dos grupos sociais antagonistas e, por essa via, à formação do pessoal encarregado ou especializado." (Bianchi, 2008, p. 74).

Para Gramsci, o conceito de intelectual não se define pelas diferentes posições que os indivíduos ocupam no mundo produtivo, estejam eles desempenhando um "trabalho manual" ou "não-manual". Diz ele que

O erro metodológico mais difundido [...] é ter buscado este critério de distinção no que é intrínseco às atividades intelectuais, em vez de buscá-lo no conjunto do sistema de relações no qual estas atividades (e, portanto, os grupos que as personificam) se encontram, no conjunto geral das relações sociais. Na verdade, o operário ou proletário [...] não se caracteriza especificamente pelo trabalho manual ou instrumental, mas por este trabalho em determinadas condições e em determinadas relaçôes sociais [...] E já se observou que o empresário, pela sua própria função, deve possuir em certa medida algumas qualificações de caráter intelectual, embora sua figura social seja determinada não por elas, mas pelas relaçôes sociais gerais que caracterizam efetivamente a posição do empresário na indústria. (Gramsci, 2000a, p. 18)

Na verdade, para Gramsci, “[...] todos os homens são intelectuais, mas nem todos os homens têm na sociedade a função de intelectuais” (Gramsci, 2000a, p.

2. Veja-se que o antiapriorismo de Gramsci é por ele manifesto por meio de sua visão epistemológica, claramente materialista, histórica e dialética: "Se é necessário, no perene fluir dos acontecimentos, fixar conceitos, sem os quais a realidade não poderia ser compreendida, deve-se também [...] fixar e recordar que realidade em movimento e conceito da realidade, se podem ser logicamente distinguidos, devem ser concebidos historicamente como unidade inseparável" (Gramsci, 1999 , p. $3 \mid$ I).

Pro-Posiçôes, Campinas, v. 22, n. 3 (66), p. 131-148, set./dez. 2011 
$18)^{3}$. Eis porque é válido adotar como eixo de interpretação dos textos gramscianos sobre os intelectuais a função que desempenharam e desempenham no complexo processo de transformação ou de conservação do modo pelo qual se desdobra a totalidade da vida social capitalista, fundada na contradição de classe. Partindo desse pressuposto marxiano fundamental, Gramsci pôde dar mais clareza ao conceito de intelectual e identificar as articuladas funções que eles exerceram na história e as que devem exercer hodiernamente os que organicamente se vincularem às classes subalternas.

O conceito gramsciano de intelectual advém da análise concreta da gênese e do desenvolvimento da dinâmica de funcionamento da formação econômica e social italiana no contexto europeu, suas contradiçôes, seus limites e suas possibilidades. E é justamente por isso que ele pode servir como parâmetro epistemológico aos que pretendem compreender a função dos intelectuais na hodierna realidade brasileira e, ao mesmo tempo, como um guia à ação sociopolítica e educativo-cultural ${ }^{4}$.

Destaque-se que, mesmo tendo a realidade italiana como objeto de reflexão e local de intervenção, Gramsci não perdeu a perspectiva cosmopolita ${ }^{5}$ e a manteve com a mesma referência à marxiana categoria de classe social. Gramsci interessou-se por conhecer o processo de formaçãa dos intelectuais e de seus grupos em vários países europeus e não europeus (Gramsci, 2000a, p. 26-32), mas com vista a conhecer historicamente a função dos intelectuais na península italiana para nela intervir e, com isso, impactar as relações sociais internacionais, pois

[...] a relação "nacional" é o resultado de uma combinação “original” única [...], que deve ser compreendida e concebida nesta originalidade e unicidade se se quer dominá-la e dirigila. [...] o desenvolvimento é no sentido do internacionalismo, mas o ponto de partida é "nacional", e é deste ponto de partida que se deve agir. (Gramsci, 2000b, p. 314).

Assim agiu Gramsci, ao resgatar historicamente o processo sociopolítico, econômico e cultural que resultou na construção do perfil de várias nações no

3. "Quando se distingue entre intelectuais e não-intelectuais, faz-se referência [...] tão-somente à imediata função social da categoria profissional dos intelectuais, isto é, leva-se em conta a direção sobre a qual incide o peso maior da atividade profissional específica, se na elaboração intelectual ou se no esforço muscular-nervoso. Isso significa que, [...] é impossível falar de não-intelectuais, porque não existem não intelectuais. [...] Não existe atividade humana da qual se possa excluir toda intervenção intelectual, não se pode separar o homo faber do homo sapiens". (Gramsci, 2000a, p. 52-53)

4. "Toda ciência é ligada às necessidades, à vida, à atividade do homem" (Gramsci, 1999, p. 174).

5. Sobre as "[...] glórias nacionais ligadas às invenções de indivíduos geniais" (Gramsci, 2000a, p. |42), é "[...] necessário [...] ressaltar o fato de que uma nova descoberta que se conserva como algo inerte não é um valor: a 'originalidade' consiste tanto em 'descobrir' quanto em 'aprofundar', em 'desenvolver' e em 'socializar', isto é, em transformar em elemento de cultura universal" (lbidem). 
estágio em que se encontravam na primeira metade do século XX. Contudo, o objetivo de entender melhor o papel dos intelectuais nesse contexto não foi cumprido plenamente, pois, mesmo tendo produzido um plano de trabalho ${ }^{6}$ para desenvolver um estudo sistemático, ele não conseguiu efetivá-lo, pelos limites do cárcere.

No cárcere, Gramsci tratou dos intelectuais principalmente no Caderno $12^{7}$. Antes da prisão, ele abordou também essa questão com profunda originalidade no contexto italiano, no ensaio denominado "Alguns temas sobre a questão meridional”, de 1926 (cf. Gramsci, 2004). Em ambos os textos, bem como em várias passagens dos Cadernos, dos escritos políticos anteriores à prisão e das cartas que escreveu, percebe-se que ele se pautou pelo compromisso de militante comunista e pelo que é fundamental ao método marxiano: a análise concreta de situações concretas (cf. Marx, 1999, p. 26-28; Marx, 1991, p. 16-17).

Historicamente, até a segunda metade do século XIX, a Itália encontrava-se fragmentada territorial, econômica, política, social e culturalmente. E, nesse processo, "[...] o fato central é precisamente a função internacional ou cosmopolita de seus intelectuais, que é causa e efeito do estado de desagregação em que permanece a península, desde a queda do Império Romano até 1870.” (Gramsci, 2000a, p. 26) E, mesmo com o difícil processo do Risorgimento (lutas pela unificação italiana, de 1815-1870), as estruturas sociais demoraram a ser alteradas, permanecendo a histórica dicotomia entre Norte e Sul.

O Sul caracterizava-se por ser, sob o ponto de vista socioeconômico, agrário e camponês e, culturalmente, tradicionalista e religioso. Nele, o modelo econômico capitalista em expansão não tinha a mesma força que adquiriu no Norte do país, pois encontrava fortes resistências culturais e ideológicas, sobretudo articuladas pela Igreja Católica e pelos intelectuais vinculados a ela. Gramsci identificou esses intelectuais comprometidos com a estrutura social "atrasada" do Sul como intelectuais tradicionais (Gramsci, 2000a, p. 22 e 23). Entre os mais típicos intelectuais tradicionais estavam os eclesiásticos, que detinham o monopólio ideológico e cultural e ligavam "o camponês meridional [...] ao grande proprietário rural” (Gramsci, 2004, p. 426). Eles não se comprometiam nem com a superação da condição de vida

6. Cf. a carta enviada do cárcere de Milão em 19.03.1925: "Estou dominado [...] por essa idéia: que precisaria fazer alguma coisa für ewig [...] Em resumo, pretenderia, segundo um plano preestabelecido, ocupar-me intensa e sistematicamente de algum tema que me absorvesse e centralizasse minha vida interior. Pensei em quatro temas até agora [...]: I. Uma pesquisa sobre $[\ldots .$.$] os intelectuais italianos [...] 2. Um estudo de lingüística comparada [...] 3. Um estudo sobre$ o teatro de Pirandello e sobre a transformação do gosto teatral italiano [...] 4. Um ensaio sobre os romances de folhetim e o gosto popular na literatura." (Gramsci, 2005, p. 128-129)

7. Um conjunto de 30 folhas incompletas e intituladas Apontamento e notas esparsas para um grupo de ensaio sobre a história dos intelectuais e da cultura na Itália.

Pro-Posiçôes, Campinas, v. 22, n. 3 (66), p. 131-148, set./dez. 2011 
do povo nem com a atualização capitalista do padrão civilizatório e produtivo da nação emergente; estavam ligados a uma estrutura social preexistente - medievalesca - que se encontrava em franca decadência (cf. Gramsci, 2000a, p. 16-17).

O Norte tinha perfil socioeconômico urbano e industrial, e ideologicamente nele predominava o liberalismo. A burguesia encontrou aí terreno fértil para se desenvolver como classe dominante economicamente e dirigente, sob o ponto de vista ético-político. Como tal, a burguesia almejou posicionar a Itália no mundo capitalista como nação, mas para tanto foi preciso criar o espírito nacional articulado pelo interesse de construir uma nação urbana e industrial. Sem essa nova visão de mundo, ficaria difícil criar as condiçôes para o desenvolvimento do capitalismo na península italiana. Tal função foi assumida por

[...] intelectuais de tipo urbano [que] cresceram junto com a indústria e são ligados às suas vicissitudes. [...] Na média geral, os intelectuais urbanos são bastante estandardizados; os altos intelectuais urbanos confundem-se cada vez mais com o estado-maior industrial propriamente dito. (Gramsci, 2000a, p. 22)

Mormente funcionários de nível médio (engenheiros, professores, advogados, etc.), os intelectuais orgânicos à burguesia assumiram a tarefa de soldar estrutura e superestrutura, isto é, adequar a ideologia na Itália às funçôes da vida prática burguesa, o que levou Gramsci a assim identificá-los: "Os intelectuais são os 'prepostos' do grupo dominante para o exercício das funções subalternas da hegemonia social e do governo político" (Gramsci, 2000a, p. 21), funçôes que o comunista da Sardenha coligou aos intelectuais de outras formações econômicas e sociais também, europeias e não europeias ${ }^{8}$. Ao atuarem dessa forma, os intelectuais colaboraram significativamente no processo de forja do bloco histórico ${ }^{9}$ burguês, articulando estrutura e superestrutura ${ }^{10}$, da "[...] qual os intelectuais são precisamente os 'funcionários'." (Ibidem, p. 20).

No cenário italiano de construção de um novo bloco histórico a partir da e para a consolidação da Itália como nação capitalista desenvolvida, destacaram-se, entre os intelectuais orgânicos à burguesia, o fascista de inspiração idealista, Gentile,

8. Os EUA guardam singularidades, pois ali "[...] deve-se notar a ausência, em certa medida, dos intelectuais tradicionais [...] Ocorreu a formação maciça de todas as superestruturas modernas com base na indústria" (Gramsci, 2000, p. 29)

9. Com o conceito de bloco histórico, Gramsci quis se referir a um conjunto de forças sociais coesas, no qual a estrutura econômica encontra correspondência na ideologia reinante, e por ela procura fazer subsumir as contradições inexoravelmente inerentes ao modo de vida capitalista.

10. Os intelectuais constituem-se na "[...] camada social encarregada de gerir a superestrutura do bloco histórico" (Portelli, 1990, p. 48). 
Benito Mussolini e o liberal Croce ${ }^{11}$. Eles estavam comprometidos em garantir que a visão de mundo do povo e sua decorrente prática social estivessem em sintonia com o desenvolvimento da nova estrutura econômica da nação italiana. E, assim, ao mesmo tempo, resistiram à penetração de outras visões de mundo e práticas sociais, como é o caso da comunista, pois ela poderia contaminar a subjetividade da nação italiana e comprometer todo o processo de reestruturação da vida social que se desdobrava sob a égide urbano-industrial burguesa.

Interessante observar que Gramsci constatou que, no mundo que emergiu das formações econômicas e sociais medievais, a escola era um dos principais aparelhos de reprodução da visão de mundo e da sociabilidade burguesa, e também por ele entendida como responsável pela formação dos intelectuais.

[...] assim como se buscou aprofundar a "intelectualidade" de cada indivíduo, buscou-se igualmente multiplicar as especializações e aperfeiçoá-las. Isso resulta das organizaçōes escolares de graus diversos, até os organismos que visam a promover a chamada "alta cultura", em todos os campos da ciência e da técnica. (A escola é o instrumento para elaborar os intelectuais de diversos níveis. A complexidade da função intelectual nos vários Estados pode ser objetivamente medida pela quantidade das escolas especializadas e pela sua hierarquização: quanto mais extensa for a "área" escolar e quanto mais numerosos forem os "graus" "verticais" da escola, tão mais complexo será o mundo cultural, a civilização, de um determinado Estado. (Gramsci, 2004, p. 19) ${ }^{12}$

A perspectiva de análise da situação histórica da Itália e o compromisso de militante comunista levaram Gramsci a indicar a necessidade de forjar outro tipo intelectual orgânico, este vinculado às classes subalternas: os operários do Norte e os camponeses do Sul (cf. Gramsci, 2004, p. 415-416), na tentativa de superar a “[...] a ideologia que foi difundida capilarmente pelos propagandistas da burguesia entre as massas do Norte: o Sul é a bola de chumbo que impede progressos mais rápidos para o desenvolvimento civil da Itália” (Gramsci, 2004, p. 409) e, assim, ter condições de produzir, a partir da articulação dos subalternos, uma nova realidade não capitalista na Itália. E tais intelectuais orgânicos às classes subalternas

II. Este "[...] cumpriu uma altíssima função 'nacional': separou os intelectuais radicais do Sul das massas camponesas, levou-os a participarem da cultura nacional e européia e, através desta cultura, fez com que fossem absorvidos pela burguesia nacional e, portanto, pelo bloco agrário" (Gramsci, 2004, p. 431 ).

12. Essa constatação de Gramsci é coerente com o entendimento que tinha de que a superestrutura social é uma instância da realidade concreta que se desenvolve de forma dialeticamente articulada com a estrutura: "A diferente distribuição dos diversos tipos de escola (clássica e profissional) no território 'econômico' e as diferentes aspirações das várias categorias destas camadas determinam, ou dão forma, à produção dos diferentes ramos de especialização intelectual. Assim, na Itália, a burguesia rural produz sobretudo funcionários estatais e profissionais liberais, enquanto que a burguesia urbana produz técnicos para a indústria." (Gramsci, 2004, p. 20)

Pro-Posiçôes, Campinas, v. 22, n. 3 (66), p. 131-148, set./dez. 2011 
não deveriam ser "O velho tipo de intelectual [que] era o elemento organizador de uma sociedade de base predominantemente camponesa e artesã; [...] [mas] um novo tipo de intelectual: organizador técnico, o especialista da ciência aplicada" (Gramsci, 2004, p. 424), com “[...] inserção ativa na vida prática, como construtor, organizador, 'persuasor permanente', [...] sem a qual permanece 'especialista' e não se torna 'dirigente' (especialista + político)" (Gramsci, 2004, p. 53). Só assim tais intelectuais poderiam auxiliar na tarefa de colocar "[...] o proletariado urbano como protagonista moderno da história italiana e, por conseguinte, da questão meridional" (Gramsci, 2004, p. 432), um papel que os comunistas turinenses tentaram cumprir, em particular, aqueles vinculados ao L'Ordine Nuovo.

Diferentemente dos intelectuais orgânicos à burguesia, os intelectuais orgânicos ao proletariado deveriam organizar as classes subalternas para o processo de luta pela libertação das condições de exploradas economicamente e dirigidas éticopoliticamente, o que exigiria a construção de um novo bloco histórico, orientado pelos interesses e pelas necessidades das classes dominadas e dirigidas, que na Itália se encontravam divididas econômica e ideologicamente entre Norte e Sul, um problema amplamente debatido por Gramsci ${ }^{13}$. Entre as dificuldades para tanto estava o fato de que a versão do capitalismo da primeira metade do século XX era mais desenvolvida do que aquela "atrasada" que marcou o final do século XIX e que ainda estava presente na Rússia antes de 1917. Identificado por Gramsci como o capitalismo das "sociedades ocidentais", este imprimiu sérios obstáculos ao processo revolucionário, porque nele as classes subalternas comportavam-se como tal não apenas porque eram obrigadas pela força dos aparelhos jurídicos, políticos e repressivos do Estado - sociedade política -, mas também porque estavam convencidas a assim agirem de forma subalterna graças à visão de mundo por elas partilhada, e que foi produzida e difundida pela burguesia, pelos seus intelectuais orgânicos e pelos aparelhos privados e públicos de que dispunham para produzir consensos sociais - sociedade civil ${ }^{14}$. De maneira que a realidade italiana era deveras diferente daquela em que os bolcheviques produziram a revolução pela "guerra de movimento"15. Em grande parte da Europa, a dinâmica do modo de produção

13. Cf. "A questão meridional", Gramsci, 2004.

14. "[...] o Estado tem e pede o consenso, mas também 'educa' este consenso através das associações políticas e sindicais, que, porém, são organismos privados deixados à iniciativa particular da classe dirigente." (Gramsci, 2000b, p. I19). Ou seja, "[...] poder-se-ia dizer que Estado = sociedade política + sociedade civil, isto é, hegemonia couraçada de coerção" (Ibidem, p. 244).

15. "No período posterior a 1870, com a expansão colonial européia, todos estes elementos se modificam, as relações de organização internas e internacionais do Estado tornam-se mais complexas e robustas; e a fórmula da 'revolução permanente', própria de 1848, é elaborada e superada na ciência política com a fórmula da 'hegemonia civil'. Ocorre na arte política o que ocorre na arte da militar: a guerra de movimento transforma-se cada vez mais em guerra de posição [...]" (Gramsci, 2000b, p. 24, grifos nossos) 
da vida social era reproduzida no âmbito subjetivo e intersubjetivo por diferentes e novos meios de difusão, tornando os comportamentos, os valores, as ideias, os desejos e as vontades dos variados grupos sociais consoantes ao modelo econômico capitalista e à classe que o dominava e dirigia. Eis uma constatação que corrobora a clássica assertiva marxiana de que "As idéias da classe dominante são, em todas as épocas, as idéias dominantes [...] a classe que é o poder material dominante da sociedade é, ao mesmo tempo, o seu poder espiritual dominante." (Marx; Engels, 1984, p. 56, grifos dos autores).

Esse novo contexto italiano e o desafio de forjar um intelectual orgânico às classes subalternas fizeram Gramsci formular um novo tipo de escola, a escola unitária, uma escola que visa a superar as de tipo clássico e profissional ${ }^{16}$. Entre os propósitos mais importantes da escola unitária estava o de formar o "[...] novo homem da classe subalterna, tendo como fim a reforma intelectual e moral do coletivo social" (Martins, 2000, p. 26), ou seja, intelectuais: indivíduos, grupos e organizações sociais que pudessem promover as condições de transformação da realidade vigente, por meio do exercício de três funções básicas: científico-filosóficas, educativo-culturais e políticas, articulando "[...] novas relações entre trabalho intelectual e trabalho industrial, não apenas na escola, mas em toda a vida social" (Gramsci, 2004, p. 40).

\section{A tríplice tarefa dos intelectuais orgânicos às classes subalternas}

Considerando a classista compreensão gramsciana exposta, é possível dizer que o intelectual orgânico às classes subalternas é o indivíduo ou a organização social (sindicato, partido político, etc.) que se propõe a assumir inúmeras tarefas no processo de superação da sociedade de classes, sobretudo três com perfis dialeticamente articulados: as de cunho científico-filosófico, as educativo-culturais e as políticas.

Entende-se por tarefas de cunho científico-filosófico aquelas cujo objetivo é compreender a dinâmica da vida societária em uma determinada formação econômica e social, em seu processo de gênese e desenvolvimento histórico e suas contradições, seus limites e suas possibilidades. Além disso, ao intelectual orgânico às classes subalternas caberá, nesse processo, formular uma visão de mundo que seja condizente com as necessidades e os interesses históricos dos trabalhadores do campo e da cidade, disseminando-a na coletividade por diferentes meios, forjando

16. "[...] as escolas de tipo profissional, [...] predominam sobre a escola formativa [...]. O aspecto mais paradoxal reside em que este novo tipo de escola aparece e é louvado como democrático, quando, na realidade, não só é destinado a perpetuar as diferenças sociais, como ainda cristalizálas em formas chinesas. [E] A escola tradicional era oligárquica já que se destinava à nova geração de grupos dirigentes, destinada por sua vez a tornar-se dirigente." (Gramsci, 2004, p. 49)

Pro-Posiçóes, Campinas, v. 22, n. 3 (66), p. 131-148, set./dez. 2011 
outra cultura ${ }^{17}$ e as condições de produção de outro bloco histórico, este sob a hegemonia do proletariado, o que é indispensável para a superação do modo de vida capitalista.

Agindo assim, ele terá condições de questionar a visão de mundo hegemônica e, ao mesmo tempo, apresentar alternativas às classes subalternas na disputa pela hegemonia, elevando a outro patamar a compreensão que têm da realidade, possibilitando-lhes a sensibilização em relação ao processo de exploração econômica, de alienação social e de subalternidade ético-política a que estão submetidas, para mobilizá-las a lutar em busca da superação dessa sua condição histórica vivida sob a égide do modo de vida capitalista.

Tal tarefa científico-filosófica só se realiza se estiver articulada à tarefa educativo-cultural. Segundo Gramsci, as "sociedades ocidentais" desenvolveram-se de tal forma que a totalidade da vida individual e social dos sujeitos das classes subalternas não é determinada direta e imediatamente pela posição que ocupam no âmbito das relações econômicas, nem apenas e tão somente pela coerção imposta pela classe dominante economicamente por meio da força dos aparelhos da "sociedade política", que estão em suas mãos pelo fato de terem se apropriado do Estado. Para se contrapor a essa compreensão mecanicista da dinâmica da realidade concreta, que contaminou parte dos pensadores marxistas (vide os da II Internacional), Gramsci formulou sobre esse problema uma resposta dialética, sustentada no conceito de "Estado integral": "[...] poder-se-ia dizer que Estado = sociedade política + sociedade civil, isto é, hegemonia revestida de coerção...” (Gramsci, 2000b, p. 244). Segundo esse conceito, há, entre a estrutura econômica, de um lado, e as superestruturas jurídico-políticas e ideológicas, de outro, uma relação mediatizada, que se desenvolve pela interposição de processos e de aparelhos sociais chamados de "sociedade civil", os quais buscam formular, difundir e consolidar visões de mundo no meio social, visando à adequação das massas à direção moral e intelectual da classe dominante economicamente.

Esse processo desenvolvido por meio da "sociedade civil" guarda dimensões éticas e educativas. Éticas no sentido de que os aparelhos da "sociedade civil", na realidade capitalista que se consolidou ao longo do século XX, visam a adequar a ação individual e coletiva, tendo como referência a visão de mundo da classe

17. "Criar uma nova cultura não significa apenas fazer individualmente descobertas 'originais'; significa também, e sobretudo, difundir criticamente verdades já descobertas, 'socializá-las' por assim dizer; e, portanto, transformá-las em base de ações vitais, em elemento de coordenação e de ordem intelectual e moral. $\bigcirc$ fato de que uma multidão de homens seja conduzida a pensar coerentemente e de maneira unitária a realidade presente é um fato 'filosófico' bem mais importante e 'original' do que a descoberta, por parte de um 'gênio filosófico', de uma nova verdade que permaneça como patrimônio de pequenos grupos intelectuais." (Gramsci, 1999 , p. 95-96) 
dominante; e educativas porque tal processo depende, também, da difusão e da assimilação, pelo coletivo social, da visão de mundo da classe dominante, o que é feito pelos processos educacionais, seja por meio do aparelho escolar ${ }^{18}$, seja por meio de outros aparelhos e processos educacionais não escolares.

É nesse sentido que se pode dizer que a educação em Gramsci é eminentemente política, ao mesmo tempo que, para ele, as relações de poder desenvolvidas nas típicas "sociedades ocidentais" têm uma dimensão educativa. Isso porque, para Gramsci, os processos de ensino-aprendizagem desenvolvidos na escola e fora dela estão articulados à disputa pela hegemonia entre as classes e, concomitantemente a isso, a política desenvolvida nas "sociedades ocidentais" exige que se ensinem os indivíduos e os grupos sociais a viver de acordo com as necessidades e os desejos da classe que é dominante economicamente. Foi essa visão do cenário político em que viveu que fez Gramsci afirmar que a "[...] tarefa dos intelectuais é determinar e organizar a reforma moral e intelectual, isto é, adequar a cultura à função prática [...]" (Gramsci, 1999, p. 126).

Assim, a educação é vista por Gramsci como fundamental à estratégia de construção do socialismo, pois, se a burguesia educa as classes subalternas para continuarem a viver na condição de subalternidade, é necessário que as classes subalternas façam o embate também no campo ideológico-cultural, educando-se para que possam forjar uma nova visão de mundo e disseminá-la no meio social, com vistas a potencializar lutas que resultem na revolução do modo de vida social.

Portanto, a função educativo-cultural do intelectual orgânico efetivar-se-á na medida em que ele se integrar organicamente ao povo, aos seus espaços e a suas ações, para sentir o que o povo sente (Gramsci, 1999, p. 221-222) e, assim, melhor compreendê-lo e mobilizá-lo para a ação revolucionária, o que exigirá uma reforma moral e intelectual. Logo, o intelectual orgânico às classes subalternas precisa educar-se para, junto com as classes às quais se vinculou vitalmente, educá-las também em um processo "[...] autocrítico necessári[o] para as correções de percurso [...]”(Máximo, 2000, p. 95), o que exigirá dele a readequação de seus princípios, valores, ideias, perspectivas, métodos de ação, práticas sociais e lingua-

18. "A tendência atual é a de abolir qualquer tipo de escola 'desinteressada' (não imediatamente interessada) e 'formativa', ou de conservar apenas um seu reduzido exemplar, destinado apenas a uma pequena elite de senhores e de mulheres que não devem pensar em prepararse para um futuro profissional, bem como a de difundir cada vez mais as escolas profissionais especializadas, nas quais o destino do aluno e sua futura atividade são predeterminados. A crise terá uma solução que, racionalmente, deveria seguir esta linha: escola única inicial de cultura geral, humanista, formativa, que equilibre de modo justo o desenvolvimento da capacidade de trabalhar manualmente (tecnicamente, industrialmente) e o desenvolvimento das capacidades de trabalho intelectual. Deste tipo de escola única, através de repetidas experiências de orientação profissional, passar-se-á a uma das escolas especializadas ou ao trabalho produtivo." (Gramsci, 2004, p. 33-34)

Pro-Posiçóes, Campinas, v. 22, n. 3 (66), p. 131-148, set./dez. 2011 
gem, para colaborar na construção de um "bloco ideológico" com "força material” (Gramsci, 2000b, p. 53) suficiente para produzir e difundir uma nova visão de mundo, até torná-la senso comum, em oposição ao "bloco ideológico" burguês, elevando a consciência popular até o ponto de nela promover uma "catarse"19, condição indispensável aos subalternos para superarem a condição de indivíduos submissos e indiferentes e, ao mesmo tempo, projetarem-se na luta econômica e política como classe, adquirindo mais consciência de si e do mundo; rompendo com a passividade política; e empreendendo novas ações, objetivando transformar radicalmente as relaçóes sociais capitalistas.

Com efeito, a "catarse" das classes subalternas - um processo eminentemente educativo-político articulado à vida econômica e social - e a decorrente maior projeção delas na disputa pela hegemonia são indispensáveis à superação da condição de dominadas e dirigidas para tornarem-se dominantes e dirigentes, mas caminhando historicamente na construção de uma realidade que não comporta a própria divisão de classes. Então, a responsabilidade dos intelectuais orgânicos às classes subalternas é objetiva e subjetiva: dedicar-se à construção de um tipo de formação social igualitária sob o ponto de vista das condições econômicas, sociais, políticas e culturais, porque o que caracteriza tal realidade é a liberdade, a autocriação humana, e não a dominação e a direção de um grupo social sobre os demais, que resultou historicamente na exploração econômica e na alienação social de indivíduos, grupos e classes sociais.

Considerando que "Toda relação de 'hegemonia' é necessariamente uma relação pedagógica” (Gramsci, 1999, p. 399), isto é, que todo processo de disputa de poder entre as classes nas “sociedades ocidentais" pressupõe um exercício heurístico, bem como a formulação e a sedimentação de conhecimentos, valores, práticas sociais e concepção de mundo, pode-se dizer que a compreensão científico-filosófica e educativo-cultural gramsciana é profundamente contaminada pela política, ao mesmo tempo que a política é vista por Gramsci como um processo que se efetiva não apenas por meio da coerção dos aparelhos de Estado ("sociedade política"), mas também pela formulação e consolidação de consensos sociais, produzidos e "cimentados" pelos aparelhos da "sociedade civil", que guardam, assim, clara função educativa.

19. "Pode-se empregar a expressão 'catarse' para indicar a passagem do momento puramente econômico (ou egoísta-passional) ao momento ético-político, isto é, a elaboração superior da estrutura em superestrutura na consciência dos homens. Isto significa, também, a passagem do 'objetivo ao subjetivo' e da 'necessidade à liberdade'. A estrutura, de força exterior que esmaga o homem, assimilando-o e o tornando passivo, transforma em meio de liberdade, em instrumento para criar uma nova forma ético-política, em origens de novas iniciativas. A fixação do momento 'catártico' torna-se assim, parece-me, o ponto de partida de toda filosofia da práxis; o processo catártico coincide com a cadeia de sínteses que resultam do desenvolvimento dialético." (Gramsci, 1999, p. 3|4-315). 
Destarte, a compreensão da realidade, a formulação de uma nova visão de mundo e sua disseminação na coletividade deverá ocorrer, para Gramsci, por meio do engajamento orgânico dos intelectuais com as classes subalternas, para que possam interagir com elas com vistas a construírem, juntos, organizações e desenvolverem ações com força social suficiente para forjarem um novo bloco histórico em oposição ao bloco hegemônico burguês. Na disputa pela dominação e pela direção da formação econômica e social, que exige a articulação de coerção e consenso na prática educativo-política, o resultado esperado é que o "bloco histórico" formado pelas classes subalternas e seus intelectuais conquiste a hegemonia, o que só será atingido se a correlação de forças lhes for favorável, de forma a produzir as condições para instituírem um novo modo de vida social resultante da reforma moral e intelectual ${ }^{20}$, que se manifesta concretamente em uma nova estrutura socioeconômica que supere a capitalista (Gramsci, 2000b, p. 19).

Desta feita, quando Gramsci se reporta a "intelectuais orgânicos”, por "intelectual" ele se refere não a um tipo específico de indivíduo, aquele que tem formação filosófica ou científica especializada, pois para ele o intelectual pode ou não ser diplomado. Quando menciona o termo “intelectual”, ele está identificando uma pessoa ou um grupo delas, uma organização social, por exemplo, que tenha condições e capacidades para fazer a análise crítica da dinâmica de funcionamento da sociedade, produzir uma visão de mundo; e a "vontade" para agir orientado por ela, para garantir que o funcionamento da coletividade ocorra segundo os interesses das classes subalternas, o que é feito por meio de um processo coletivo com uma dimensão educativa que envolve os intelectuais e o povo.

Por sua vez, quando se refere ao termo “orgânico”, Gramsci remete-se ao engajamento vital do intelectual com as classes fundamentais de um determinado modo de vida social. Para Gramsci, "orgânico” é o compromisso vital que os intelectuais podem ter com as classes no processo que travam na disputa pela hegemonia em uma totalidade sócio-histórica, que, no caso de Gramsci, foi a da Itália da primeira metade do século XX.

20. Ao destacar a importância do embate cultural e ideológico na disputa pela hegemonia, e mesmo ao pôr em relevo o papel dos intelectuais, Gramsci não desvincula a "sociedade civil" da sociedade política, nem, muito menos, a "sociedade civil" da dinâmica da base econômica da vida social, como afirma "Bobbio, que, em seu texto $O$ conceito de sociedade civil, desvirtua a concepção dialética que Gramsci tem da relação estrutura-superestrutura, afirmando ser o revolucionário sardenho um intelectual que teria "[...] colocado 'o verdadeiro centro, o teatro da história' [...]" (Bobbio, 1982, p. 33), na "[...] sociedade civil, [que] em Gramsci, não pertence ao momento da estrutura, mas ao da superestrutura." (Ibidem, p. 32 - grifos do autor). "Na realidade, ao contrário do que se crê, Gramsci deriva o seu conceito de sociedade civil não de Marx, mas declaradamente de Hegel [...]" (Ibidem, p. 34), afirmação que seria suficiente para identificar Gramsci como um idealista, um novo Croce. (Martins, 2008a, p. 224-225)

Pro-Posiçôes, Campinas, v. 22, n. 3 (66), p. 131-148, set./dez. 2011 
Pelo exposto sobre as tarefas científico-filosóficas, educativo-culturais e políticas dos intelectuais, pode-se inferir que, enquanto os intelectuais orgânicos à classe dominante e dirigente do modo de vida capitalista são conservadores, porque assumem como função primordial promover a reprodução do modo de vida social ao nível da subjetividade, da intersubjetividade e da prática social, os intelectuais orgânicos às classes subalternas têm outra função, a revolucionária: formular, disseminar e consolidar na dinâmica da vida social uma visão de mundo que seja capaz de se tornar força social com potencial suficiente para promover concretamente a transformação radical do modo de vida.

Feitas essas considerações, resta ressaltar quatro observações: primeira, que os intelectuais não são uma classe social, mas um indivíduo ou, no máximo, um grupo ou organização social; segunda, os intelectuais orgânicos não se confundem com a classe a que estão organicamente vinculados e nem lhe são completamente externos, pois, mesmo articulados vitalmente, os intelectuais guardam certa autonomia relativa e têm uma consciência mais clara - porque mais racional, radical, rigorosa e de conjunto - em relação à dinâmica da realidade da vida social; terceira observação: um dos papéis destacados dos intelectuais na disputa pela hegemonia é cooptar outros "intelectuais", sejam os "tradicionais", sejam os "orgânicos" à outra classe ${ }^{21}$. Quando ocorre a cooptação, Gramsci a identifica como "transformismo"22; quarta observação: na realidade atual é possível identificar intelectuais progressistas engajados politicamente e, ao mesmo tempo, não orientados pela categoria de classe, isto é, não revolucionários e, nesse sentido, não orgânico às classes subalternas. Progressistas ${ }^{23}$, porque seu engajamento político foca o equacionamento de determinados problemas sociais originários da dinâmica de funcionamento da sociedade de classe; e não classistas, não revolucionários, porque

21. "Formam-se assim, historicamente, categorias especializadas para o exercício da função de intelectual; formam-se em conexão com todos os grupos sociais, mas sobretudo em conexão com os grupos sociais mais importantes, e sofrem elaborações mais amplas e complexas em ligação com o grupo social dominante. Uma das características mais marcantes de todo grupo que se desenvolve no sentido do domínio é sua luta pela assimilação e pela conquista 'ideológica' dos intelectuais tradicionais, assimilação e conquista que são tão mais rápidas e eficazes quanto mais o grupo em questão for capaz de elaborar simultaneamente seus próprios intelectuais orgânicos." (Gramsci, 2000a, p. 18-19).

22. Assiste-se, no Brasil, a "transformismos" de toda ordem, seja o "transformismo molecular", seja o "transformismo de grupos", afetando os intelectuais das classes subalternas, que "[...] passam individualmente [ou como] conjuntos inteiros da elite consciente e ativa das massas [...] ao bloco histórico dominante." (Saviani, 2005, p. 23)

23. Há, também, hodiernamente, intelectuais conservadores engajados politicamente, mas o que este texto está procurando esclarecer são algumas confusões que se cometem na utilização do conceito gramsciano de intelectual orgânico, recorrentemente utilizado para identificar a ação de intelectuais progressistas, estejam eles ou não orientados pela categoria de classe em sua ação política. 
a atuação política desses intelectuais na vida social ocorre por meio da identidade não de classe, mas por outras (étnicas, de gênero, opção sexual etc.); portanto, eles não têm como escopo fundamental a superação do elemento determinante da sociedade capitalista, que são as contradições de classes, como expressa Gramsci em sua produção teórica e em sua vida de militante revolucionário, que podem ser identificadas como as de um intelectual orgânico às classes subalternas, pois Gramsci não apenas defendeu o engajamento político dos intelectuais a partir da categoria de classe, mas efetivamente viveu isso concretamente por meio da ação sindical, partidária e educativo-cultural que teve com o objetivo de produzir uma revolução socialista.

\section{À guisa de conclusão: Marx e Gramsci como intelectuais orgânicos}

O posicionamento gramsciano sobre os intelectuais é interessante principalmente sob três aspectos: primeiro, porque dá sequência aos esforços da teoria marxiana para entender qual foi o papel desempenhado pelos intelectuais ao longo da história, seguindo as pistas de Marx, principalmente em sua famosa "XI Tese sobre Feuerbach"24; segundo, porque o ponto de vista gramsciano projeta a discussão sobre os intelectuais para além da relação entre "trabalho manual" e "trabalho intelectual", mas sem desconsiderar este debate clássico no interior do marxismo; terceiro, porque ajuda a compreender melhor a relação entre os intelectuais e a dinâmica da vida social em uma formação econômica e social específica, como a presente realidade brasileira.

Além disso, deve-se dizer que a presente leitura da concepção gramsciana de intelectual instiga a aproximá-la da marxiana, com a qual mantém mais proximidades do que distanciamentos. No que concerne à discussão em tela, indiscutivelmente, ambos foram intelectuais orgânicos às classes subalternas, compreenderam a necessidade de o proletariado contar com forças socioculturais que mantêm relativa autonomia em relação a eles no processo de desencadeamento e efetivação da revolução social almejada, além do que, entenderam que as ideias da classe dominante são as ideias dominantes na formação econômica e social capitalista.

Resta aos que se interessam por essa temática reler os textos gramscianos para deles inferir outras interpretações, já que são escritos abertos. Aos comprometidos com a transformação das relações sociais globais e, particularmente, com a construção de outra realidade societária no Brasil, também é importante retomar os escritos gramscianos, pois neles se encontram interessantes apontamentos que servem de guia para a ação política, sobretudo os que trabalham com a educação em uma perspectiva classista.

24. "Os filósofos se limitaram a interpretar o mundo de diferentes maneiras; mas o que importa é transformá-lo." (Marx, 1986, p. 128, grifos do autor).

Pro-Posiçóes, Campinas, v. 22, n. 3 (66), p. 131-148, set./dez. 2011 


\section{Referências bibliográficas}

BIANCHI, Á. O laboratório de Gramsci: filosofia, história e política. São Paulo: Alameda, 2008.

BOBBIO, N.; MATTEUCCI, N.; PASQUINO, G. Dicionário de política. Trad. de Carmen C. Varrialle et al. 4. ed. Brasília-DF: Editora da UNB, 1992.

GOHN, M. da G. Movimentos sociais e educação. São Paulo: Cortez, 2009.

GRAMSCI, A. Cadernos do cárcere. Antonio Gramsci: introdução ao estudo da filosofia. A filosofia de Benedetto Croce. Ed. e trad. de Carlos N. Coutinho. Coed. de Luiz S. Henriques e Marco A. Nogueira. Rio de Janeiro: Civilização Brasileira, 1999. v. 1.

GRAMSCI, A. Cadernos do cárcere, v. 2 - Antonio Gramsci: os intelectuais. O princípio educativo. Jornalismo. Ed. e trad. de Carlos N, Coutinho. Coed. de Luiz S. Henriques e Marco A. Nogueira. Rio de Janeiro: Civilização Brasileira, 2000a.

GRAMSCI, A. Cadernos do cárcere, v. 3 - Antonio Gramsci: Maquiavel. Notas sobre o Estado e a política. Ed. e trad. de Carlos N. Coutinho. Coed. de Luiz S. Henriques e Marco A. Nogueira. Rio de Janeiro: Civilização Brasileira, 2000b.

GRAMSCI, A. Escritos políticos, v. 2. Org. e trad. de Carlos N. Coutinho. Rio de Janeiro: Civilização Brasileira, 2004.

GRAMSCI, A. Cartas do cárcere, v. 1: 1926-1930 - Antonio Gramsci. Trad. de Luiz S. Henriques. Org. Carlos N. Coutinho e Luiz S. Henriques. Rio de Janeiro: Civilização Brasileira, 2005.

MARTINS, M. F. Ensino técnico e globalização: cidadania ou submissão? Campinas-SP: Autores Associados, 2000. (Col. Polêmicas do nosso tempo, v. 71)

MARTINS, M. F. Marx, Gramsci e o conhecimento: ruptura ou continuidade? CampinasSP: Autores Associados; Americana-SP: Unisal, 2008a. (Col. Educação contemporânea).

MARTINS, M. F. Pedagogia do engajamento: considerações sobre a desumanização e as possibilidades de sua superação. Práxis Educativa, Ponta Grossa- PR, v. 3, n. 1, p. 55-66, jan.-jun. 2008b.

MARX, K. Teses sobre Feuerbach. In: MARX, K.; ENGELS, F. A ideologia alemã (Feuerbach). Trad. de José C. Bruni e Marco A. Nogueira. 5. ed. São Paulo: Hucitec, 1986.

MARX, K. Prefácio. In: MARX, K. Para a crítica da economia política. Trad. de José C. Bruni, José A. Giannotti, Edgard Malagodi e Walter Rehfeld. 5. ed. São Paulo, Abril Cultural, 1991. (Col. Os pensadores; v. 12).

MARX, K. O capital: crítica da economia política. Trad. de Reginaldo Sant'Ana. 17. ed. Rio de Janeiro: Civilização Brasileira, 1999. v. 1 e 2.

MARX, K.; ENGELS, F. A ideologia alemã. São Paulo: Moraes, 1984. $1^{\circ}$ cap. seguido das Teses sobre Feuerbach. 
MAXIMO, A. C. Os intelectuais e a educação das massas. Campinas-SP: Autores Associados, 2000. (Col. Polêmicas do nosso tempo; v. 76)

ORTEGA Y GASSET, José. A rebelião das massas. 3. ed. Rio de Janeiro: Livro IberoAmericano, 1971.

PICOLOTTO, E. L. Movimentos sociais: abordagens clássicas e contemporâneas. CSOnline - Revista Eletrônica de Ciências Sociais, ano 1, n. 2, nov.- 2007. Disponível em: http://www.editoraufjf.com.br/revista/index.php/csonline/article/view/358. Acesso em: 15 mar. 2011.

PORTELLI, H. Gramsci e o bloco histórico. 5. ed. Trad. de Angelina Peçanha. São Paulo: Paz e Terra, 1990.

SAVIANI, D. Gramsci na educação brasileira. In: RAGAZZINI, D. Teoria da personalidade na sociedade de massa - a contribuição de Gramsci. Trad. de Maria de L. M. Campinas-SP: Autores Associados, 2005.

Recebido em 23 de agosto de 2010 e aprovado em 17 de junho de 2011. 